\title{
RANCANG BANGUN PROTOTYPE KAPAL PENDETEKSI DAN PENGAMBIL SAMPAH OTOMATIS BERBASIS ARDUINO NANO
}

\author{
Teguh Hidayat Iskandar Alam ${ }^{1}$, Ermin $^{2}$ \\ ${ }^{1,2}$ Fakultas Teknik Program Studi Teknik Informatika Universitas Muhammadiyah Sorong \\ erminhimatif3771@gmail.com
}

\begin{abstract}
The condition of waste in the city of Sorong is currently the center of attention of the public in general because of the piles of garbage in the sea. Increasing population and changing lifestyles of the community, has increased the amount of waste and the public's unconsciousness in disposing of waste in a place that causes various problems, one of which is the problem that often accumulates garbage in the sea.

The purpose of this study is to automatically detect waste based on urduino nano by ship mechanical design and electronics. Arduino nanobased garbage detection and automatic garbage picker prototype is designed from mechanical design, electronic components and program design.

The design of automated programs as a goal to clean up garbage in the sea without human intervention and can maintain the marine ecosystem because the entire work process of the ship is done by the system. Thus from the results of the pilot testing the ship's prototype can work according to its function as an automatic trash picker and detector.
\end{abstract}

Keywords: Waste Detection Vessel, Arduino, DC Motor, Ultrasonic Sensor, Servo Motor

\begin{abstract}
Abstrak
Kondisi sampah di kota sorong saat ini menjadi pusat perhatian masyarakat pada umumnya di sebabkan tumpukan sampah di laut. Bertambah jumlah penduduk dan perubahan gaya hidup masyarakat, telah meningkatkan jumlah sampah serta ketidaksadaran masyarakat dalam membuang sampah tidak pada tempatnya sehingga menimbulkan berbagai masalah, salah satu masalah diantaranya yang sering terjadi menumpuknya sampah di laut.

Tujuan dari penelitian ini untuk mendeteksi sampah secara otomatis berbasis urduino nano dengan desain mekanika dan elektonik Kapal. Prototype kapal pendeteksi sampah dan pengambil sampah otomatis berbasis arduino nano di rancang dari desain mekanik, komponen elektronik dan rancagan program.

Perancangan program otomatis sebagai tujuan untuk membersihkan sampah dilaut tanpa campur tangan manusia dan dapat menjaga ekosistem laut karena seluruh proses kerja kapal di kerjakan oleh system. Dengan demikian dari hasil uji coba kerja prototype kapal dapat bekerja sesuai dengan fungsinya sebagai pendeteksi dan pengambil sampah otomatis.
\end{abstract}

Kata Kunci :Kapal Pendeteksi Sampah Arduino, Motor DC, Sensor Ultrasonik, Motor Servo

\section{Pendahuluan}

\section{Latar Belakang}

Kondisi sampah di kota sorong saat ini menjadi pusat perhatian masyarakat pada umumnya di sebabkan tumpukan sampah di laut. Bertambah jumlah penduduk dan perubahan gaya hidup masyarakat, telah meningkatkan jumlah sampah serta ketidaksadaran masyarakat dalam membuang sampah tidak pada tempatnya sehingga menimbulkan berbagai masalah, salah satu masalah diantaranya yang sering terjadi menumpuknya sampah di laut. Sampah yang terdapat di laut dalam jumlah kecil maupun besar tentu dapat menimbulkan pencemaran lingkungan dan merusak ekosistem. Di laut yang seharusnya menjadi taman rekreasi dan menjadi sumber pendapatan daerah menjadi berkurang sehingga perlu perhatian serius untuk menanganinya.

Saat ini belum ada kapal pendeteksi dan pengambil sampah otomatis yang berada di kota Sorong. Sehingga di butuhkan sebuah prototype yang bisa mendeteksi sampah dan mengambil sampah secara otomatis. Oleh karena itu untuk mengatasi masalah tersebut, Maka di butuhkan kapal pendeteksi sampah dan pengambil sampah secara otomatis. Berdasarkan masalah diatas, maka penulis membuat "Rancang Bangun Prototype Kapal Pendeteksi Dan
Pengambil Sampah Otomatis Berbasis Arduino Nano" yangdapat membantu mengatasi masalah kebersihan laut yang di hadapai oleh masyarakat maupun pemerintah kota Sorong.

\section{Landasan Teori}

\section{State Of The Art (Kajian Terhadap Penelitian} Terdahulu)

Dalam penyusunan penelitian ini bersumber beberapa jurnal yang terkait yang saling beririsan dengan judul penulis teliti.

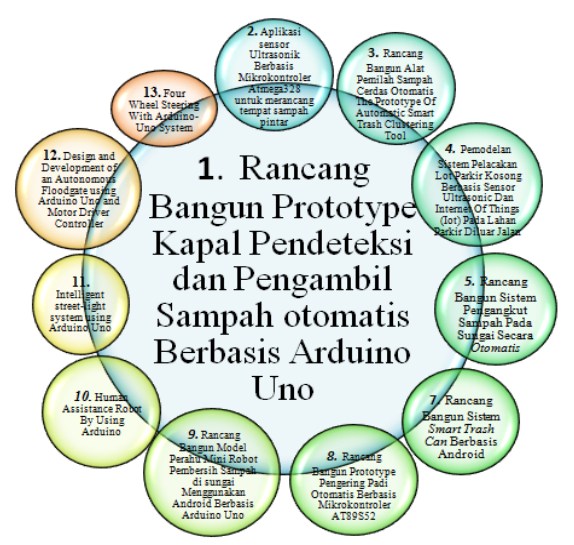




\section{Studi Literatur}

\subsection{Arduino Nano}

Arduino nano adalah papan rangkain elektronik open source yang didalamnya terdapat komponen utama yaitu, sebuah chip mikrokontroler. Penulis menggunakan Arduino nano dalam penelitian ini sebagai microkontroller dengan bahasa pemrograman yang mengirimkan perintah pada komponen-komonen hardware yang terhubung. Dimana komponen-komponen tersebut adalah sensor menerima perintah mendeteksi sampah dan motor DC menerima perintah menggerakan kapal serta mengaktifkann motor servo sebagai alat mengambil sampah. Sebagai USB-toserial converter untuk komunikasi serial ke computer melalui port USB.

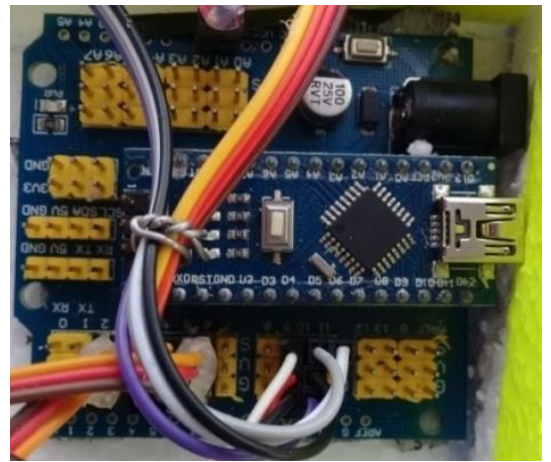

Gambar 2.2.1 Arduino nano

\subsection{Sensor Ultrasonik}

Sensor ultrasonik adalah sebuah sensor yang berfungsi untuk mengubah besaran fisis (bunyi) menjadi besaran listrik dan sebaliknya. Cara kerja sensor ini didasarkan pada prinsip dari pantulan suatu gelombang suara sehingga dapat dipakai untuk menafsirkan eksistensi (jarak) suatu benda dengan frekuensi tertentu.

Secara umum, alat ini akan menembakkan gelombang ultrasonik menuju suatu area atau suatu target. Setelah gelombang menyentuh permukaan target, maka target akan memantulkan kembali gelombang tersebut.

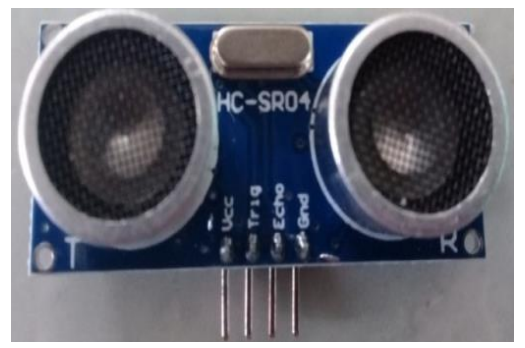

Gambar 2.2.2 Sensor Ultrasonik

Penulis menggunakan sensor ultrasonik dalam penelitian ini sebagai pendeteksi sampah yang terhubung dengan conveyor, dimana conveyor akan berputar secara otomatis setelah menerima perintah dari arduino uno untuk mengambil sampah.

\subsection{Motor DC}

Motor DC merupakan suatu mesin listrik berfungsi sebagai motor listrik apabila terjadi proses konversi energi listrik menjadi energi mekanik di dalamnya. Motor DC merupakan suatu mesin listrik berfungsi sebagai motor listrik apabila terjadi proses konversi energi listrik menjadi energi mekanik di dalamnya. . Prinsip kerja dari arus searah adalah membalik phasa tegangan dari gelombang yang mempunyai nilai positif dengan menggunakan komutator, dengan demikian arus yang berbalik arah dengan kumparan jangkar yang berputar dalam medan magnet. Bentuk motor paling sederhana memiliki kumparan satu lilitan yang bisa berputar bebas di antara kutubkutub magnet permanen. (Irmah Wahyuni, 2015).

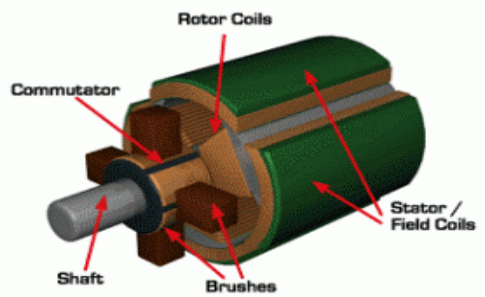

Gambar 2.2.3 Motor DC

Sumber:https://crizkydwi.wordpress.com/2014/11/05/motor-dc-dan-generator-dc/

\subsection{Saklar}

Saklar adalah sebuah perangkat yang digunakan untuk memutuskan jaringan listrik, atau untuk menghubungkannya. Selain untuk jaringan listrik arus kuat, saklar berbentuk kecil juga dipakai untuk alat komponen elektronika arus lemah. (Yudha Elasya dkk, 2016)

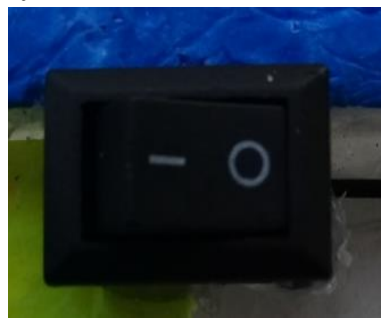

Gambar 2.2.4 Saklar

\subsection{Motor Servo}

Motor servo adalah sebuah motor DC dengan sistem umpan balik tertutup di mana posisi rotornya akan diinformasikan kembali ke rangkaian kontrol yang ada di dalam motor servo. Penulis menggunakan Motor Servo dalam penelitian ini sebagai pengambilan sampah yang di deteksi oleh sensor, setelah menerima perintah dari arduino. Sampah di ambil oleh motor servo kemudian di angkat ke bak sampah.

\subsection{Software Arduino IDE}

Software Arduino Integrated Development Enviroment (IDE) adalah suatu software yang khusus digunakan untuk memprogram mikrokontroler bermerek Arduino. Software Arduino IDE ini bisa dimiliki secara gratis dan dapat didownload pada website. Dan Software Arduino IDE ini tersedia untuk platform Windows, Mac OS X, dan LINUX. (Yudha Elasya dkk, 2016). Penulis menggunakan Software Arduino Integrated Development Enviroment (IDE) dalam 
penelitian ini digunakan untuk mengedit program, mengubah bahasa $\mathrm{C}$ ke bahasa biner kemudian upload dari komputer ke arduino.

\subsection{Pengertian Flowchart}

Flowchart adalah penggambaran secara grafik dari langkah-langkah dan urut-urutan prosedur dari suatu program. Flowchart digunakan untuk merepresentasikan maupun mendesain program. Penulis menggunakan flowchart sebagai alur penelitian atau proses, menampilkan langkah-langkah proses dengan berbagai symbol yang dihubungkan dengan panah. Oleh karena itu flowchart harus bisa merepresentasikan komponen-komponen dalam bahasa pemrograman (Adelia, 2011).

\section{Metode Penelitian}

\subsection{Bagan Alur Penelitian}

Bagan alur penelitian dibentuk dengan tujuan mengoptimalkan proses penelitian agar lebih teratur dan sistematis.

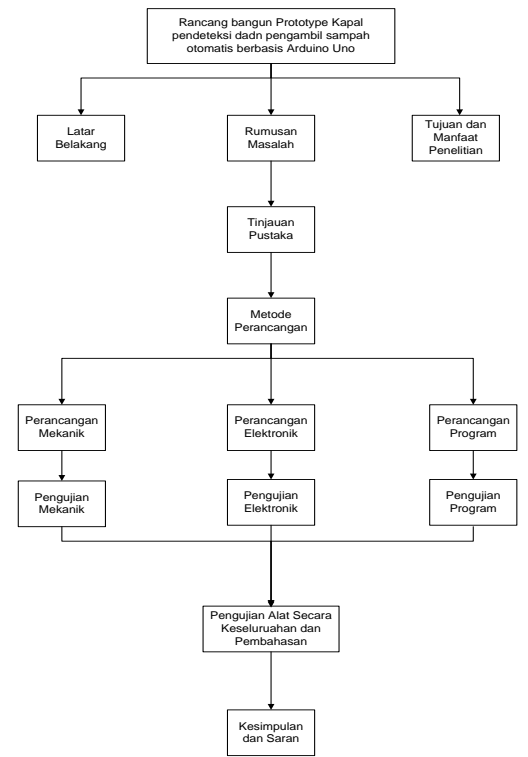

Gambar 3.1. Bagan Alur Penelitian

\subsection{Perancangan Alat}

Pada bab akan membahas proses yang akan dilakukan terhadap alat yang akan di buat dari perancangan rangkaian hingga hasil yang di fungsikan. Secara garis besar perancangan prototype kapal pendeteksi dan pengambil sampah otomatis berbasis arduino nano, dibagi menjadi tiga bagian yaitu perancangan mekanik, perancangan elektronik dan perancangan program.

\subsubsection{Perancangan Mekanik}

Dalam perancangan mekanik ini, jenis arduino nano yang digunakan pada sistem ini adalah ATmega328, adapun gambar rangkaian keselurhan dapat dilihat pada gambar 3.2.1

\subsubsection{Perancangan Elektronik}

Pada bab ini akan di bahas tentang perancangan alat sistem arduino uno yang menjelaskan prinsip kerja dari masing-masing blok diagram, yang akan di pasang pada prototype kapal sebagai koneksi jalan dan gerakannya prototype kapal melalui sistem arduino nano.

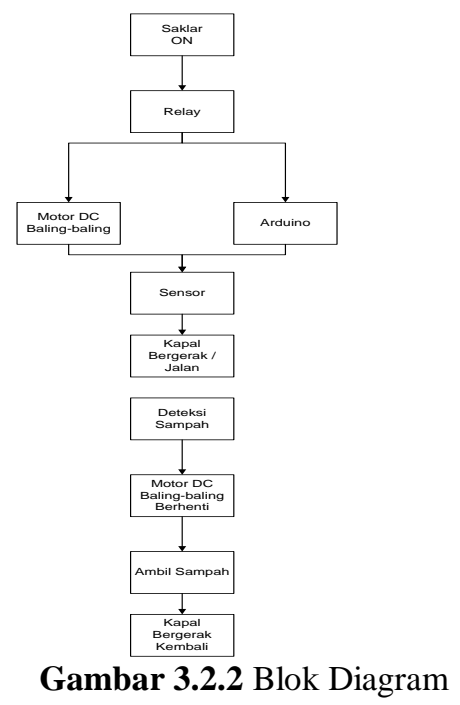

Dari blok diagram diatas dapat dilihat kondisi sensor ultrasonik sebagai pendeteksi sampah dan pengambil sampah yang di proses oleh arduino nano dan bagian output yang terdiri dari motor servo dan motor DC Baling-baling.

\subsubsection{Perancangan Program}

Cara kerja rangkaian keseluruhan kapal adalah dengan perintah 1 Jika sensor mendeteksi sampah maka sensor akan mengirim sinyal ke arduino nano kemudian arduino nano memberi perintah kepada motor servo ON (bergerak) untuk mengambil sampah.

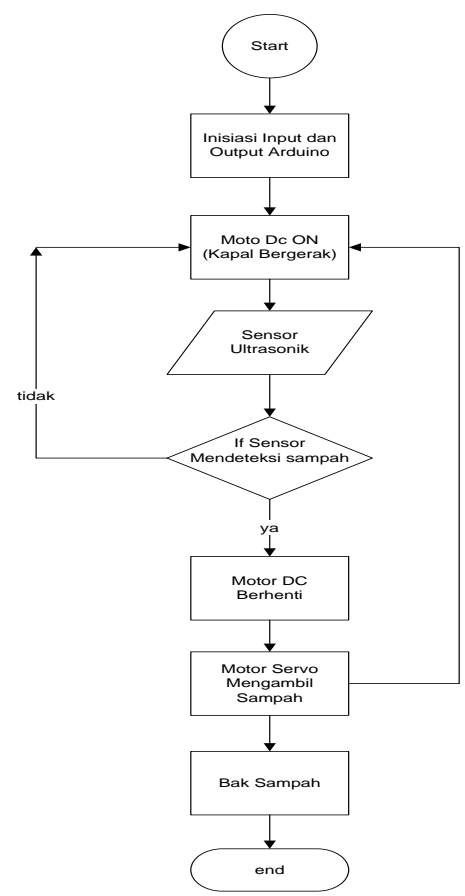


Gambar 3.2.3 Flowchart

\subsubsection{Pengujian Alat Secara Keseluruhan}

Dalam tahap pengujian alat ini adalah sebagai Proses pengambilan data untuk mengetahui alat berfungsi dengan baik atau tidak.

\subsection{Lokasi dan waktu penelitian}

Penelitian ini berlokasi UM-Sorong yang akan ditunjukan pada penelitian ini bermaksud mendapatkan data-data yang tepat untuk evaluasi lebih lanjut. Waktu penelitian akan dilaksanakan pada tahun 2018 sesuai jadwal dalam lampiran. Penulis turun melakukan penelitian selama 2 bulan terhitung mulai tanggal 01 Oktober - 30 November 2018.

\section{Pengujian Dan Pembahasan}

\subsection{Pengujian Perancangan Mekanik}

Dalam proses pengujian mekanika kapalprototype ini, tidak menemukan masalah, karena bahan-bahannya terbuat dari gabus/steraform. Selain proses pembuatanya relatif muda kemudian tidak mudah tenggelam disaat pengujian berlangsung di air

Berikut adalah gambar hasil dari perancangan kapal pendeteksi sampah dan pengambil sampah otomatis berbasis arduino nano.

\subsection{Pengujian Elektronik}

Pada bab ini akan di bahas tentang pengujian elektronik kapal pendeteksi sampah dan pengambil sampah otomatis. Alat-alat tersebut menjelaskan prinsip kerja dari masingmasing komponen dengan dilakukan proses pengujian untuk memastikan alat tersebut dapat berfungsi dengan baik atau tidak.

\subsubsection{Pengujian Catu Daya}

Dalam penelitian ini catu daya tempat dudukannya terletak dibelakang kapal yang mempunyai peranan sebagai penyuplai energy listrik pada rangkaian kapal. Pengujian catu daya Pada penelitian ini menggunakan catu daya baterai dengan tegangan 12 volt. dan kapasitas baterai sebesar 2300 $\mathrm{mAh}$. Dengan kapasitas $2300 \mathrm{mAh}$ dapat memberikan daya kepada perahu selama 2 jam.

\subsubsection{Pengujian Sensor Ultrasonik}

Dalam Pengujian sensor ultrasonik pada penelitian ini bertujuan untuk mengetahui kinerja dari sensor ultrasonik dalam membaca jarak pada suatu objek. Pengujian dilakukan berdasarkan simulasi nyata pada kapal pendeteksi sampah Secara otomatis. Adapun hasil pengujian pada sistem kerja sensor ultrasonik di tunjukan pada tabel 4.2

\begin{tabular}{|c|l|}
\hline Sensor Ultrasonik & Keterangan \\
\hline Jarak deteksi $(\mathrm{Cm})$ & \\
\hline 0 & Terdeteksi \\
\hline 2 & Terdeteksi \\
\hline 4 & Terdeteksi \\
\hline 6 & Terdeteksi \\
\hline 8 & Terdeteksi \\
\hline 10 & Terdeteksi \\
\hline
\end{tabular}

\begin{tabular}{|l|l|}
\hline 12 & Terdeteksi \\
\hline 14 & Terdeteksi \\
\hline 16 & Terdeteksi \\
\hline 18 & Terdeteksi \\
\hline 20 & Terdeteksi \\
\hline 22 & tidak terdeteksi \\
\hline 24 & tidak terdeteksi \\
\hline 26 & tidak terdeteksi \\
\hline 29 & tidak terdeteksi \\
\hline 30 & tidak terdeteksi \\
\hline
\end{tabular}

Dari Tabel 4.2 dapat dilihat bahwa sensor Ultrasonik dapat mendeteksi sampah organik dan anorganik.

\subsubsection{Pengujian Motor DC}

Pengujian motor DC pada penelitian ini untuk mengetahui kinerja dari motor DC dalam menggerakkan kapal pendeteksi sampah dan pengambil sampah. Bila sensor mendeteksi sampah, maka motor DC akan berhenti. Kemudian Motor Servo mengambil sampah secara otomatis.

\subsubsection{Pengujian Motor Servo}

Pengujian motor servo dalam penelitian ini sebagai pengambil sampah yang di deteksi oleh sensor, kemudian sensor mengirim sinyal ke arduino. Arduino memberi perintah pada motor servo kemudian motor servo megambl sampah ke bak sampah.

\subsubsection{Pengujian Arduino Nano}

Pengujian arduino nano dalam penelitian ini sebagai microkontroller dengan bahasa pemrograman yang mengirimkan perintah pada komponen-komponen hardware yang terhubung. Dimana komponen-komponen tersebut adalah sensor menerima perintah mendeteksi sampah dan motor DC menerima perintah menggerakan kapal serta mengaktifkann motor servo sebagai alat mengambil sampah.

\subsubsection{Pengujian Saklar}

Proses pengujian saklar ini, jika on maka dapat menghantarkan arus liistrik ke suluruh rangkaian elektroik kapal dan jika tidak maka tidak menghantarkan arus listrik ke komponen elektronik kapal. Sehingga dipastikan saklar dapat bekerja dengan baik

\subsubsection{Pengujian Driver Motor}

Proses pengujian driver motor, pada prototype kapal pendeteksi dan pengambil sampah otomatis digunakan sebagai kontrol motor dc untuk bekerja secara efektif / menggerakan baling-baling.

\subsubsection{Pengujian Pembagi Arus}

Proses pengujian pembagi arus dalam penelitian ini sebagai penurun tegangan dari 12 volt ke 9 volt atau 5 volt.

\subsection{Pengujian Keseluruhan Kapal Pendeteksi Sampah Dan Pengambil Sampah Otomatis}

Berikut adalah gambar hasil dari perancangan mekanik dan elektronik prototype kapal pendeteksi sampah dan pengambil sampah otomatis berbasis arduino nano. Hasil perancangan dapat dilihat pada gambar 4.4 di bawah ini. 


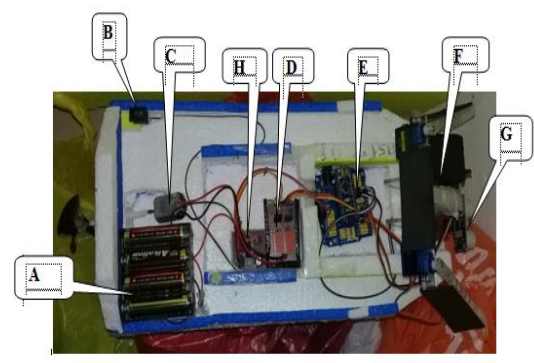

Keterangan :
A. Baterai $12 \mathrm{~V}$ sebagai catu daya atau sumber tenaga dari kapal
B. Saklar digunakan sebagai menghidupakan dan mematikan seluruh rangkaian arus listrik.
C. Motor DC sebagai penggerak kapal atau menjalankan kapal
D. Driver Motor sebagai Pengontrol motor jalannya motor dc
E. Arduino Nano di sini Sebagai pusat kendali dari prototype kapal pendeteks dan pengambil sampah
F. Motor Servo sebagai pengambil sampah / penjempit sampah
G. Sensor Ultrasonik berfungsi sebagai pendeteksi objek / sampah
H. Pembagi arus digunakan sebagai Pembagi arus dari baterai ke motor dc, arduino, motor servo dan sensor ultrasonic.

Pengujian ini dilakukan berdasarkan simulasi pada sistem kerja kapal secara keseluruhan. Hasil yang diambil adalah data dari setiap pengujian. Pengujian awal dilakukan saat kapal dihidupkan dengan memindahkan posisi saklar dari posisi off menjadi on, arus listrik yang masuk dari sumber catu daya akan diubah menjadi tegangan DC dan akan ditransfer ke setiap komponen sesuai dengan kebutuhan. Keluaran 5,032 Volt DC digunakan untuk menyuplai sensor ultrasonik, motor servo, Keluaran 8,99 Volt DC digunakan untuk menyuplai board Mikrokontroler ATMega328, sedangkan keluaran 31,41 Volt DC digunakan untuk menyuplai beban motor DC.

Ketika alat dihidupkan, Motor DC mengambil peran untuk mnggerakan kapal kemudian Sensor ultrasonik yang sedang dalam posisi stand by (tidak mendeteksi objek di atas $20 \mathrm{~cm}$ ) memiliki tegangan sebesar 5,044 Volt DC dengan arus sebesar 3,241 mA, lalu pada saat sensor ultrasonik mendeteksi objek dengan jarak dibawah $20 \mathrm{~cm}$, sensor akan bekerja dan tegangannya menjadi sebesar 5,038 Volt DC dengan arus sebesar 3,23 mA. Saat itu Motor DC berhenti selama 1000 detik kemudian motor servo mengambil peran untuk mengambil sampah. Setelah proses pengambilan sampah selesai motor DC kembali menggerakan kapal.

\section{Kesimpulan dan Saran \\ 5.1 Kesimpulan}

Setelah dilakukannya pengujian dan analisa, selanjutnya dapat diperoleh kesimpulan yaitu sebagai berikut :

1. Telah dibuat rancang bangun kapal pendeteksi sampah dan pengambil sampah otomatis yang terdiri dari dua komponen yaitu kapal pendeteksi sampah dan pengambil sampah. Kapal memiliki panjang $33 \mathrm{~cm}$, lebar $18 \mathrm{~cm}$, tinggi $9 \mathrm{~cm}$ dengan rangka yang dari gabus/steroform sedangkan alat pengambil sampah terbuat dari aluminium dan plastik.

2. Alat ini berhasil dan dapat bekerja sesuai dengan fungsinya sebagai pendeteksi dan pengambil sampah otomatis.

3. Alat pendeteksi sampah otomatis ini dapat bekerja jika sensor ultrasonik yang berjarak dari objek sampah 0-20 $\mathrm{cm}$ kemudian motor servo mengambil sampah.

\subsection{Saran}

Dalam penelitian ini, masih terdapat kekurangan dalam beberapa aspek dan perlu pengembangan sebagai berikut ;

1. Alat ini berhasil dan dapat bekerja sesuai dengan fungsinya sebagai pendeteksi sampah. Tetapi Tidak dapat memilah sampah organik dan anorganik. Sehingga sistemnya dapat di kembangkan untuk penelitian selanjutnya.

2. Pada kapal system ini belum di lengkapi dengan sensor pembatas sampah, agar ketika bak sampah penuh maka system kerja kapal berhenti. Oleh karena itu dapat di tambahkan dan dikembangkan pada penelitian berikutnya.

\section{Ucapan Trimakasih}

\section{Bismillahirrahmnirrahim.}

\section{Assalamualaikum $\mathrm{Wr}$. Wb.}

Limpahan syukur yang tak henti-hentinya kita panjatkan kepada Allah SWT. Atas rahmat, karunia, serta hidayah dan curahan kasih sayang-Nya sehingga penulis dapat menyelesaikan tugas akhir dengan judul Rancang Bangun Prototype Kapal Pendeteksi Dan Pengambil Sampah Otomatis Berbasis Arduino Nano.Dan tidak lupa pula Shalawat dan salam kepada Rasulullah SAW sebagai sosok teladan ummat dalam segala perilaku keseharian yang berorientasi kemuliaan hidup di dunia dan akhirat.

Penulis menyampaikan terima kasih yang terkhusus, teristimewa, dengan penuh ketulusan dan penulis dedikasikan tugas akhir ini kepada ayahanda dan ibunda tercinta (Bapak La Isondo dan Ibu Wa Isongke) yang telah mencurahkan kasih sayang serta doa yang tiada henti-hentinya demi kebaikan, keberhasilan dankebahagiaan penulis.

Penulis ingin menyampaikan ucapan terima kasih kepada semua pihak yang telah membantu dan membimbing dalam menyelesaikan tugas akhir ini. Pada kesempatan ini, Penulis menyampaikan terima kasih kepada :

1. Bapak Ir. Irman Amri, ST., M.T selaku Dekan Fakutas Teknik Universitas Muhammadiyah Sorong yang telah memberikan berbagai kemudahan, baik administrasi maupun moril kepada kami selama masa pendidikan. 
2. Bapak Rendra Soekarta, S.Kom., M.T selaku Ketua Program Studi Teknik Informatika Universitas Muhammadiyah Sorong sekaligus selaku dosen pembimbing II yang telah banyak memberikan motivasi dan dorongan kepada kami selama perkuliahan sampai pada penyelesaian tugas akhir.

3. Bapak Teguh Hidayat Iskandar Alam, S.Kom., M.MT. Selaku dosen pembimbing I yang penuh ketulusan hati meluangkan waktu, tenaga, dan pikiran serta penuh kesabaran untuk membimbing, mengarahkan da memotivasi penulis di saat penulis mengalami kesulitan dalam menyeselesaikan tugas akhir ini.

4. Bapak David Piter Raymond Luhukay, S.Si Selaku Guru SMA Averos yang telah meluangkan waktu, tenaga, dan pikiran serta membimbing sehingga proses penelitian ini dapat berjalan dengan baik.

Akhir kata penulis berharap tugas akhir ini dapat berguna bagi penulis dan dapat bermanfaat bagi rekanrekan mahasiswa untuk perkembangan teknologi.

\section{Daftar Pustaka}

A.S. Thenge dkk. (2017). Four Wheel Steering With ArduinoUno System , 333-336.

Adlin Fakhrana. (2016). Pembuatan Prototype Robot Kapal Pemungut Sampah Menggunakan Mikrokontroler Arduino Uno Dengan Aplikasi Pengendali Berbasis Android, 185-195.

Aishwarya. N. Patil dkk. (2017). Intelliggent Street-Light System using Arduino UNO .

Athur Daniel Limantara dkk. (2017). PEMODELAN SISTEM PELACAKAN LOT PARKIR KOSONG BERBASIS SENSOR ULTRASONIC DAN INTERNET OF THINGS (IOT) PADA LAHAN PARKIR DILUAR JALAN .

Irmah Wahyuni. (2015, Agustus 19). RANCANG BANGUN SISTEM PENGANGKUT SAMPAH PADA. Dipetik juni 30, 2018, dari http://repositori.uinalauddin.ac.id/8302/1/IRMAH\%20WAHYU NI.pdf: repositori.uinalauddin.ac.id/8302/1/IRMAH\%20WAHYU NI.pdf

Jasmir, dkk. (2017). S.Com., M.Com. Miniatur Conveyor otomatis Berbasis Mikrokontroler .

MUHAMMAD MUKRIM AL MABRUR. (2016, Desember 07). Rancang Bangun Sistem Smart Trash Can Berbasis. Dipetik juni 30, 2018, dari http://repositori.uin-alauddin.ac.id/6224/: repositori.uin-alauddin.ac.id/6224

Narendra Kumar Sharivas dkk. (2017). Human Assistance Robot By Using Arduino

Prengky L.E.Aritonang dkk. (2017). RANCANG BANGUN ALAT PEMILAH SAMPAH CERDAS OTOMATIS THE PROTOTYPE OF AUTOMATIC SMART TRASH CLUSTERING TOOL .
S.M. Saifur Rahman Faisal dkk. (2017). Design and Development of an Autonomous Floodgate using Arduino Uno and Motor Driver Controller, 276-280.

Suyatno Budiharjo dkk. (2017). RANCANG BANGUN MODEL PERAHU MINI ROBOT PEMBERSIH, 30.

Teguh Hidayat I.A. (2016). S.Com., M.MT. Rancang Bangun Prototype Pengering Padi Otomatis

Yudha Elasya dkk. (2016). APLIKASI SENSOR ULTRASONIK BERBASIS MIKROKONTROLER ATMEGA328 UNTUK MERANCANG TEMPAT SAMPAH PINTAR . 